\title{
Et skritt i riktig retning
}

Bevilgningene til Det globale fondet for bekjempelse av aids, tuberkulose og malaria økte nylig med $20 \%$, men det trengs trolig en dobling av hivfinansieringen for å kunne tilby behandling til alle som trenger det.

I Tidsskriftet nr. 16/2010 uttrykte vi vår bekymring over at store givere, med USA og EU i spissen, har annonsert kutt i finansieringen til hiv-behandling (1). Dette er svært dramatisk for de ti millioner menneskene som har et akutt behov for behandling, og det er oppsiktsvekkende at dette skjer samme år som tusenårsmål nummer seks, om hiv-behandling til alle innen 2010, ikke blir oppfylt.

Målet med vårt innlegg var å overbevise norske myndigheter om å øke sine bidrag til Det globale fondet for bekjempelse av aids, tuberkulose og malaria, i forbindelse med giverlandskonferansen som ble avholdt i New York 4.-5. oktober. Gledelig nok valgte Norge, i likhet med blant annet Frankrike, å annonsere en økning til fondet i forkant av giverlandskonferansen, og ble fulgt av en rekke land under selve konfe- ransen. Sluttresultatet var en bevilgning på totalt 11,7 milliarder dollar for de neste tre årene, en økning på rundt $20 \%$, sammenliknet med perioden 2008-10 (2).

Dette er et skritt i riktig retning, men vi har fortsatt en lang vei å gå. UNAIDS har beregnet at det trengs en dobling av hivfinansieringen for å kunne tilby behandling til alle som trenger det (3). Kampen mot hiv kan vinnes, men bare gjennom langvarig og helhjertet forpliktelse fra alle aktører.

\section{Marius Trøseid}

troseid@hotmail.com

Asgeir Johannessen

Leger uten grenser

og

Infeksjonsmedisinsk avdeling

Oslo universitetssykehus, Ullevål

0407 Oslo

\section{Oppgitte interessekonflikter: Ingen}

Litteratur

1. Trøseid M, Johannessen A. Kampen mot hiv kan vinnes, men pengene mangler! Tidsskr Nor Legeforen 2010; 130: 1599-600.

2. The Global Fund to Fight AIDS, Tuberculosis and Malaria. Press release: Donors commit US\$ 11.7 billion to the Global fund for next three years. http://www.theglobalfund.org/en/pressreleases/ ?pr=pr_101005c (26.10.2010).

3. UNAIDS. What countries need. Investments needed for 2010 targets. Genève, 2009.

Manuskriptet ble mottatt 11.10. 2010. Første revisjon ble mottatt 18.10. 2010. Manuskriptet ble godkjent 21.10. 2010. Medisinsk redaktør Siri Lunde. 